\title{
The Carboxy Terminus of Tissue Factor Pathway Inhibitor Is Required for Interacting with Hepatoma Cells In Vitro and In Vivo
}

\author{
Ilka Warshawsky, ${ }^{\star}$ Guojun Bu, ${ }^{\star}$ Alan Mast, ${ }^{\ddagger}$ Jeffrey E. Saffitz, ${ }^{\S}$ George J. Broze, Jr., ${ }^{\ddagger}$ and Alan L. Schwartz \\ *Edward Mallinckrodt Departments of Pediatrics, Molecular Biology, and Pharmacology; ${ }^{\ddagger}$ Division of Hematology/Oncology, \\ Jewish Hospital; and ${ }^{\S}$ Department of Pathology at Washington University School of Medicine, St. Louis, Missouri 63110
}

\begin{abstract}
Tissue factor pathway inhibitor (TFPI) is a plasma Kunitztype serine protease inhibitor that directly inhibits coagulation Factor Xa and also inhibits tissue factor-initiated coagulation. Normal human plasma TFPI exists both as the fulllength molecule and as variably carboxy-terminal truncated forms. We reported recently that the low density lipoprotein receptor-related protein mediates the cellular degradation of TFPI after TFPI binding to the hepatoma cell surface. To examine whether the carboxy terminus of TFPI was required for interacting with hepatoma cells, a mutant of TFPI lacking the third Kunitz-type domain and basic carboxy terminus was generated. We found that this mutant, TFPI-160, did not compete with full-length ${ }^{125}$ I-TFPI-160 for binding to hepatoma cells. We were also unable to demonstrate specific binding of ${ }^{125}$ I-TFPI-160 to hepatoma cells at $4^{\circ} \mathrm{C}$. At $37^{\circ} \mathrm{C}$, significantly less ${ }^{125} \mathrm{I}$-TFPI-160 was internalized and degraded via low density lipoprotein receptor-related protein than full-length ${ }^{125} \mathrm{I}$-TFPI. Full-length ${ }^{125} \mathrm{I}$ TFPI binding to hepatoma cells could be inhibited $>90 \%$ by heparin and other highly charged molecules. Since TFPI, but not TFPI-160, was capable of effectively binding to cultured hepatoma cells, the fates of TFPI and TFPI-160 in vivo were examined. Both ${ }^{125}$ I-TFPI and ${ }^{125}$ I-TFPI-160 disappeared rapidly from the circulation after their intravenous administration into rats. The initial plasma half-life of ${ }^{125} \mathrm{I}$-TFPI was $\sim 30 \mathrm{~s}$ whereas the half-life of ${ }^{125} \mathrm{I}$-TFPI-160 was $\sim 4$ min. ${ }^{125}$ I-TFPI was cleared predominantly by the liver. In contrast, ${ }^{125}$ I-TFPI-160 accumulated in the outer cortex of the kidney. Using microscopic autoradiography, we demonstrate that ${ }^{125}$ I-TFPI clearance is largely hepatocellular, whereas ${ }^{125} \mathrm{I}$-TFPI-160 accumulates mainly in the cells of the kidney proximal tubules. Together our findings demonstrate that the carboxy-terminal region(s) distal to amino acid 160 of TFPI mediates TFPI binding to hepatoma cells both in vitro and in vivo. (J. Clin. Invest. 1995. 95:1773-
\end{abstract}

Address correspondence to Ilka Warshawsky, Department of Pediatrics, Children's Hospital, Box 8116, Washington University School of Medicine, One Children's Place, St. Louis, MO 63110. Phone: 314-4546286; FAX: 314-454-2685.

Received for publication 30 August 1994 and in revised form 18 October 1994.

1. Abbreviations used in this paper: $\alpha_{2} \mathrm{M}^{*}$, methylamine-activated $\alpha_{2}$ macroglobulin; GST, glutathione $S$-transferase; LRP, low density lipoprotein receptor-related protein; TF, tissue factor; TFPI, tissue factor pathway inhibitor.

J. Clin. Invest.

(C) The American Society for Clinical Investigation, Inc.

0021-9738/95/04/1773/09 \$2.00

Volume 95, April 1995, 1773-1781
1781.) Key words: tissue factor pathway inhibitor $\bullet$ binding - clearance $\cdot$ carboxy terminus

\section{Introduction}

Tissue factor pathway inhibitor (TFPI) ${ }^{1}$ is a trace $\sim 40-\mathrm{kD}$ plasma glycoprotein $(\sim 2.0 \mathrm{nM})$ that plays a key role in the regulation of tissue factor (TF)-initiated blood coagulation ( 1 , 2 ). TFPI was initially identified after the observation that preincubation of TF with serum prevented the lethal disseminated intravascular coagulation that occurs after TF infusion in animals $(3,4)$. This observation suggested there was an inhibitor of TF in serum. This serum inhibitor, currently called TFPI, was subsequently purified from various sources including human hepatoma HepG2 cells $(5,6)$, plasma lipoproteins (7), and postheparin plasma (8). The cDNA was cloned from human placental and fetal liver cDNA libraries (9). Mature TFPI, 276 residues, contains an acidic amino-terminal domain followed by three tandem Kunitz-type protease inhibitory domains, and a basic carboxy-terminal domain (9).

TFPI regulates coagulation via its abilities to directly inhibit coagulation Factor Xa and to inhibit the Factor VIIa-TF complex of the extrinsic pathway of blood coagulation (10). The extrinsic pathway of coagulation is initiated when damage to blood vessels at the site of a wound allows TF to gain access to the plasma. Plasma Factor VII or VIIa binds to TF and the Factor VIIa-TF complex proteolytically activates Factors IX and $\mathrm{X}$, triggering a cascade of events which eventually leads to the generation of thrombin and the formation of a fibrin clot $(1,2)$. Inhibition of the Factor VIIa-TF complex by TFPI occurs in two steps. In the first step, Factor Xa binds to the second Kunitz-type domain of TFPI, and in the second step, the TFPI-Factor Xa complex binds to the TF-Factor VIIa complex through an interaction between the first Kunitz-type domain and Factor VIIa, forming a Factor Xa-TFPI-Factor VIIa-TF complex (11). The function of the third Kunitz-type domain is not known.

The majority of circulating TFPI is not in the form of the full-length molecule but is truncated at various positions in its carboxy terminus (12). The enzyme(s) responsible for carboxy-terminal truncation has not been identified and whether proteolysis modulates TFPI activity in vivo is also not known. Using a carboxy-terminal truncated variant of TFPI lacking the third Kunitz-type domain and basic carboxy terminus (TFPI ${ }^{1-161}$ ), Hamamoto et al. (13) reported that TFPI ${ }^{1-161}$ inhibited cell surface Factor VIIa-TF proteolytic activity towards Factor X identically to full-length TFPI. Carboxy-terminal truncated TFPI and full-length TFPI have also been shown to inhibit Factor Xa and Factor VIIa-TF equally in endpoint-type assays (14). However, carboxy-terminal truncated TFPI possesses considerably less anticoagulant activity as measured in one stage coagulation assays because full-length TFPI is a more potent inhibitor of the prothrombinase complex (14-16). 
After the intravenous administration of TFPI into rabbits, TFPI is rapidly cleared from the circulation (initial $t_{1 / 2}$ of $\sim 2$ $\mathrm{min})$ and accumulates in the liver and kidney $(17,18)$. Bregengaard et al. (18) reported that the carboxy terminus of TFPI was important in mediating rapid TFPI clearance because $2 \mathrm{~min}$ after intravenous injection the recovery in plasma of TFPI ${ }^{1-161}$ was $\sim 15$-fold higher than full-length TFPI. Heparin, which binds to the basic carboxy terminus of TFPI and to a portion of the third Kunitz-type domain $(14,15)$, was found to reduce the clearance of full-length TFPI $\sim 10-15$-fold but had no effect on the clearance of TFPI ${ }^{1-161}(18)$.

Using hepatoma cell lines, we reported recently (19) that the low density lipoprotein receptor-related protein (LRP) mediates TFPI degradation. The cellular degradation of ${ }^{125}$ I-TFPI was inhibited $>80 \%$ by both antibodies directed against LRP and by the LRP-associated $39-\mathrm{kD}$ protein, a protein that copurifies with LRP and inhibits all known ligand interactions with LRP. LRP, however, does not appear to be the major cell surface receptor for TFPI since ${ }^{125} \mathrm{I}$-TFPI binding at $4^{\circ} \mathrm{C}$ is not inhibited by the $39-\mathrm{kD}$ protein. We proposed that after TFPI binds to the hepatoma cell surface, LRP mediates the cellular degradation of TFPI. The purpose of this study was to examine the importance of the carboxy terminus of TFPI in interacting with the hepatoma cell surface TFPI receptor and/or LRP both in vitro and in vivo.

\section{Methods}

Materials. Iodogen was purchased from Pierce Chemical Co. (Rockford, IL). Enzymobeads were from Bio-Rad Labs. (Richmond, CA). Carrierfree sodium [ $\left.{ }^{125} \mathrm{I}\right]$ iodide and Hyperfilm-MP were purchased from Amersham Corp. (Arlington Heights, IL). Sprague-Dawley rats were obtained from Harlan Sprague Dawley, Inc. (Indianapolis, IN). Pronase, bovine serum albumin (fraction V), and low molecular weight heparin (\#375097) were from Calbiochem-Novabiochem (La Jolla, CA). Heparin (\#H9768), heparan sulfate (\#H7641), dextran sulfate (\#D4911), pentosan polysulfate (\#P8275), chondroitan sulfate (\#C2413), and poly $\mathrm{L}$ lysine with mean molecular weights of 1-4 kD (\#P0879) and 15$30 \mathrm{kD}$ (\#P7890) were from Sigma Immunochemicals (St. Louis, MO). Tissue culture medium was from GIBCO BRL (Gaithersburg, MD). Protein A-agarose was from Repligen Corp. (Cambridge, MA). Kodak NTB-2 and Kodak D19 developer were from Eastman Kodak Co. (Rochester, NY).

Proteins. Recombinant human full-length TFPI (containing the basic carboxy terminus) was a gift from the Monsanto Co. (Chesterfield, MO). A cDNA encoding a truncated form of TFPI (TFPI-160) was constructed in which the codon triplet for glycine 160 was followed by two consecutive TGA stop codons and an appropriate HindIII restriction site. This cDNA was inserted into the pMON6875 expression vector and the production of TFPI-160 in Escherichia coli was essentially as described for full-length TFPI except that the sample was reapplied to a Q Sepharose fast flow column (Pharmacia LKB Biotechnology Inc., Piscataway, NJ), pH 8.0, instead of a mono $S$ column in the final purification step (20). After SDS-PAGE and staining with Coomassie brilliant blue, TFPI- 160 migrates as a single band of $22 \mathrm{kD}$. $\alpha_{2}$-Macroglobulin was purified from human plasma and activated by incubation with methylamine (to yield $\alpha_{2} M^{*}$ ) (21). The full-length rat 39-kD protein and constructs encoding residues 1-114 and 115-319 of the 39-kD protein were produced as fusion proteins with glutathione $S$ transferase (GST) in E. coli. The GST fusion proteins were purified by glutathione-agarose chromatography (21). The full-length GST 39-kD protein was cleaved with thrombin and free $39-\mathrm{kD}$ protein was purified via heparin-agarose chromatography (21).

Antibodies. Polyclonal rabbit antibodies were generated against fulllength human TFPI and total IgG was prepared using protein A-agarose (14).
Protein iodinations. TFPI and TFPI- $160(25$ or $50 \mu \mathrm{g})$ were iodinated using the Iodogen method (22). $\alpha_{2} \mathrm{M}^{*}(20 \mu \mathrm{g})$ was iodinated using Enzymobeads (22). Specific radioactivities were typically $0.5-4 \times 10^{7}$ $\mathrm{cpm} / \mu \mathrm{g}$ protein.

Cell binding and degradation assays. Rat hepatoma $\mathrm{MH}_{1} \mathrm{C}_{1}$ cells were cultured as described previously (22). Cells were seeded into $12-$ well dishes $2 \mathrm{~d}$ before assay. Cell monolayers were used at 80-90\% confluency. Assay buffer for TFPI and TFPI-160 was Earle's minimal essential medium (with glutamine) containing $3 \%(\mathrm{wt} / \mathrm{vol})$ bovine serum albumin (BSA). Assay buffer for $\alpha_{2} \mathbf{M}^{*}$ was Dulbecco's modified Eagle's medium containing $6 \mathrm{mg} / \mathrm{ml} \mathrm{BSA}$ and $5 \mathrm{mM} \mathrm{CaCl}_{2}$ (21). Cell monolayers were washed twice on ice with $0.5 \mathrm{ml}$ of the appropriate prechilled assay buffer and binding was initiated by adding $0.35 \mathrm{ml}$ of $4^{\circ} \mathrm{C}$ assay buffer containing the indicated concentrations of ${ }^{125} \mathrm{I}$-labeled proteins in the absence or presence of unlabeled competitors. After incubation at $4^{\circ} \mathrm{C}$ for $2 \mathrm{~h}$, buffer containing unbound ligand was removed and the cells were washed three times with $4^{\circ} \mathrm{C}$ PBS or assay buffer. The cells were then lysed in $62.5 \mathrm{mM}$ Tris- $\mathrm{HCl}, \mathrm{pH} 6.8$, containing $0.2 \%$ (wt/vol) SDS and $10 \%$ (vol/vol) glycerol (low SDS-lysis buffer) and radioactivity of cell lysates was determined in a $\gamma$ counter (model C5304; Packard Instruments, Meriden, CT). Nonspecific binding was determined in the presence of excess unlabeled ligand as specified in each figure.

Degradation assays were performed by washing cell monolayers twice with room temperature assay buffer. Then $0.35 \mathrm{ml}$ of assay buffer containing the indicated concentrations of ${ }^{125} \mathrm{I}$-labeled proteins in the absence or presence of unlabeled competitors was added for $4 \mathrm{~h}$ at $37^{\circ} \mathrm{C}$. Thereafter, the overlying medium was removed and proteins were precipitated by the addition of BSA to $5 \mathrm{mg} / \mathrm{ml}$ and trichloroacetic acid to $10 \%$. Degradation of ligand was defined as the appearance of radioactive ligand fragments in the overlying medium that were soluble in trichloroacetic acid. Degradation of ${ }^{125} \mathrm{I}$-ligand in parallel dishes that did not contain cells has been subtracted from the total degradation. After removal of the overlying medium, the cell monolayers were washed three times with PBSc (PBS containing $1 \mathrm{mM} \mathrm{CaCl}_{2}$ and 0.5 $\mathrm{mM} \mathrm{MgCl}$ ). Cells were then lysed in low SDS-lysis buffer and cellassociated radioactivity was quantified. Alternatively, cells were incubated for $30 \mathrm{~min}$ at $4^{\circ} \mathrm{C}$ with PBSc containing $0.25 \%$ (wt/vol) Pronase, which removes cell surface radioligand and also detaches cells from the culture wells. The detached cells were separated from the buffer by centrifugation. Radioactivity of the supernatant fractions (defining cell surface Pronase-sensitive radioligand) and radioactivity associated with the cell pellets (defining internalized Pronase-resistant radioligand) were determined separately. Cellular protein per well was determined using a Bio-Rad protein assay with BSA as a standard.

In vivo plasma clearance. Female Sprague-Dawley rats (weighing $200-220 \mathrm{~g}$ ) were anesthetized with sodium pentobarbital $(15 \mathrm{mg} / 200$ $\mathrm{g}$ rat) during the time of the experiment. ${ }^{125} \mathrm{I}$-TFPI or ${ }^{125} \mathrm{I}-\mathrm{TFPI}-160$, $\left(6-8 \times 10^{6} \mathrm{cpm}\right.$ ) in sterile $0.15 \mathrm{M} \mathrm{NaCl}$ (total volume $500 \mu \mathrm{l}$ ), was injected into a tail vein over $30 \mathrm{~s}$. Blood samples $(50-100 \mu \mathrm{l})$ (total volume $<800 \mu \mathrm{l}$ ) were collected from the tail artery at the indicated times after injection into tubes containing $10 \mu \mathrm{l}$ of $0.5 \mathrm{M}$ EDTA. Each of the blood samples was centrifuged, and 10-20 $\mu \mathrm{l}$ of the plasma fractions was spotted onto 3-mm filter paper (Whatman Inc., Clifton, $\mathrm{NJ}$ ), precipitated with $10 \%$ trichloroacetic acid, rinsed with ethanol, and ${ }^{125}$ I-radioactivity was determined. The initial plasma concentrations ( time $=0$ ) of ${ }^{125}$ I-TFPI and ${ }^{125}$ I-TFPI-160 were obtained by extrapolating the amount of radioactivity from the first two (TFPI) or six (TFPI160) measured samples. At the times specified in the text, the animals were killed and the liver, kidneys, and spleen were removed, blotted, weighed, and ${ }^{125}$ I-radioactivity was determined.

Autoradiography. Samples of the kidneys and livers from rats injected with ${ }^{125}$ I-TFPI or ${ }^{125}$ I-TFPI- 160 were fixed with $10 \%$ phosphatebuffered formalin and embedded in paraffin. Sections of embedded tissues were mounted on gelatin-coated slides, deparaffinized, rehydrated with water, and then air dried. Some slides were directly placed against Hyperfilm-MP for $\mathbf{4 0} \mathrm{d}$. Other slides were covered with a photographic emulsion (Kodak NTB-2) for the indicated periods of time before development with Kodak D19 developer diluted 1:1 with water. These slides 

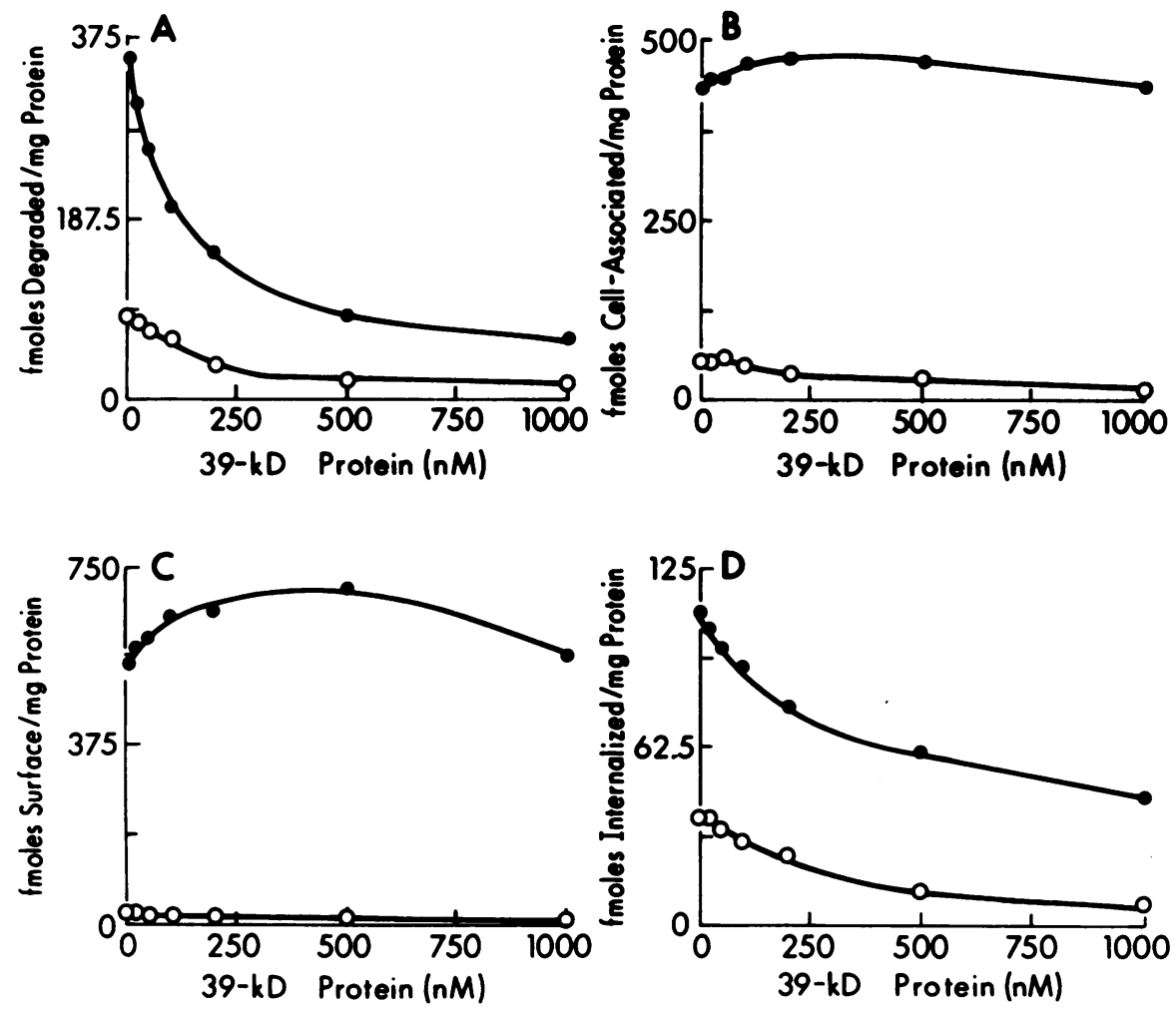

Figure 1. Effect of the $39-\mathrm{kD}$ protein on the cellular degradation, cellular association, and internalization of ${ }^{125}$ I-TFPI and ${ }^{125}$ I-TFPI160. Rat hepatoma $\mathrm{MH}_{1} \mathrm{C}_{1}$ cells were incubated with $2.5 \mathrm{nM}{ }^{125} \mathrm{I}$-TFPI $(\bullet)$ or $10 \mathrm{nM}$

${ }^{125} \mathrm{I}$-TFPI-160 $(O)$ in the absence or presence of increasing concentrations of the $39-\mathrm{kD}$ protein for $4 \mathrm{~h}$ at $37^{\circ} \mathrm{C}$. Thereafter the overlying medium was removed and proteins were subjected to trichloroacetic acid precipitation. The cell monolayers were then washed to remove unbound ligand and either directly lysed (with SDS) to determine cell-associated radioactivity or, alternatively, the cell monolayers were treated with Pronase. In $A$, trichloroacetic acid-soluble radioactivity, representing degraded radioligand is shown. $B$ demonstrates cell-associated radioactivity after lysis of the cell monolayers with SDS. In $C$, cell surface (Pronase-sensitive) radioligand is indicated. $D$ shows internalized (Pronase-resistant) radioligand. Radioactivity was converted to femtomole equivalents of ${ }^{125}$ I-TFPI and ${ }^{125}$ I-TFPI- 160 calculated from the specific activities and is normalized per milligram of protein. Each symbol represents the average of duplicate determinations from two separate experiments. were then stained with hematoxylin and eosin and examined microscopically to delineate grain distributions.

Immunoprecipitations. Plasma samples from the indicated time points of rats injected with ${ }^{125}$ I-TFPI $(25 \mu \mathrm{l})$ or ${ }^{125} \mathrm{I}$-TFPI-160 $(15 \mu \mathrm{l})$ or $\sim 100,000 \mathrm{cpm}$ of starting ${ }^{125}$ I-TFPI and ${ }^{125}$ I-TFPI-160 were mixed with PBS (final volume $500 \mu \mathrm{l}$ ) and immunoprecipitated with $10 \mu \mathrm{g}$ of total anti-TFPI IgG/sample at $4^{\circ} \mathrm{C}$ for $4 \mathrm{~h}$ (TFPI samples) or overnight (TFPI-160 samples). $60 \mu \mathrm{l}$ of a $50 \%$ slurry of protein A-agarose was added for $2 \mathrm{~h}$ at $4^{\circ} \mathrm{C}$. Nonspecifically bound radioactivity was removed by washing the protein $\mathrm{A}$-agarose beads three to four times with PBS containing $1 \%$ ( vol/vol) Triton X-100, 0.5\% (wt/vol) sodium deoxycholate, $1 \%$ (wt/vol) SDS, and $0.5 \%$ (wt/vol) BSA. The immunoprecipitated material was released from the beads by boiling each sample for $5 \mathrm{~min}$ in $62.5 \mathrm{mM}$ Tris- $\mathrm{HCl}, \mathrm{pH} \mathrm{6.8,2 \%} \mathrm{(wt/vol)} \mathrm{SDS,}$ $10 \%$ (wt/vol) glycerol, and 5\% (vol/vol) 2-mercaptoethanol (Laemmli sample buffer) (23). The entire plasma immunoprecipitates and $\sim 10,000 \mathrm{cpm}$ of the starting immunoprecipitates were subjected to $12.5 \%$ SDS-PAGE. The gels were fixed, dried, and exposed to film.

\section{Results}

Effect of the 39-kD protein on the cellular degradation and cellular association of ${ }^{125}$ I-TFPI and ${ }^{125}$ I-TFPI-160. We reported previously that LRP mediates the cellular degradation of ${ }^{125}$ I-TFPI after ${ }^{125} \mathrm{I}$-TFPI binding to the hepatoma cell surface (19). To examine whether the carboxy terminus of TFPI was important for interacting with hepatoma cells/LRP, a construct encoding amino acids 1-160 of TFPI was produced in $E$. coli and purified. This construct, TFPI-160, consists of the first two Kunitz-type domains of TFPI and lacks the third Kunitz-type domain and basic carboxy terminus. The ability of the $39-\mathrm{kD}$ protein to alter LRP-mediated degradation of ${ }^{125} \mathrm{I}$-TFPI-160 was examined by incubating rat hepatoma $\mathrm{MH}_{1} \mathrm{C}_{1}$ cells with $10 \mathrm{nM}$ ${ }^{125} \mathrm{I}$-TFPI-160 in the absence or presence of increasing concentrations of the $39-\mathrm{kD}$ protein for $4 \mathrm{~h}$ at $37^{\circ} \mathrm{C}$. As a control, 2.5
$\mathrm{nM}$ of full-length ${ }^{125} \mathrm{I}$-TFPI was similarly incubated with $\mathrm{MH}_{1} \mathrm{C}_{1}$ cells. Thereafter, the medium overlying the cell monolayers was subjected to trichloroacetic acid precipitation, and trichloroacetic acid-soluble radioactivity, representing degraded ligand, was determined. As seen in Fig. $1 A$ and as demonstrated previously (19), the 39-kD protein inhibits the cellular degradation of ${ }^{125} \mathrm{I}$-TFPI in a dose-dependent manner. The $K_{\mathrm{i}}$ value ${ }^{2}$ for inhibition is $\sim 70 \mathrm{nM}$. Degradation of ${ }^{125} \mathrm{I}$-TFPI (initial concentration $2.5 \mathrm{nM}$ ) is reduced from $308 \mathrm{fmol} / \mathrm{mg}$ protein in the absence of the $39-\mathrm{kD}$ protein to $65 \mathrm{fmol} / \mathrm{mg}$ protein in the presence of $1 \mu \mathrm{M} 39-\mathrm{kD}$ protein. The $39-\mathrm{kD}$ protein also inhibits the cellular degradation of ${ }^{125}$ I-TFPI-160 (initial concentration $10 \mathrm{nM}$ ) in a dose-dependent manner. Degradation is reduced from $89 \mathrm{fmol} / \mathrm{mg}$ protein in the absence of the $39-\mathrm{kD}$ protein to $18 \mathrm{fmol} / \mathrm{mg}$ protein in the presence of $1 \mu \mathrm{M} 39-\mathrm{kD}$ protein.

We next examined whether the $39-\mathrm{kD}$ protein alters the cellular association of ${ }^{125} \mathrm{I}$-TFPI and ${ }^{125} \mathrm{I}$-TFPI-160. After incubation at $37^{\circ} \mathrm{C}$ for $4 \mathrm{~h}$, the overlying medium was removed and the cells were rinsed to remove unbound ligand. Cells were then lysed in a buffer containing $0.2 \%$ SDS, and radioactivity of the cell lysates was determined. Fig. $1 B$ demonstrates that the $39-\mathrm{kD}$ protein has no effect on the cellular association of ${ }^{125}$ I-TFPI. The cellular association of ${ }^{125} \mathrm{I}$-TFPI-160 (initial concentration $10 \mathrm{nM}$ ), however, is reduced from $55 \mathrm{fmol} / \mathrm{mg}$ protein in the absence of the $39-\mathrm{kD}$ protein to $17 \mathrm{fmol} / \mathrm{mg}$ protein in the presence of $1 \mu \mathrm{M} 39-\mathrm{kD}$ protein.

We reported previously that LRP is not the major receptor for TFPI on the hepatoma cell surface since the $39-\mathrm{kD}$ protein did not inhibit ${ }^{125} \mathrm{I}$-TFPI binding at $4^{\circ} \mathrm{C}(19)$. The inability of the $39-\mathrm{kD}$ protein to inhibit the cellular association of ${ }^{125} \mathrm{I}$-TFPI

2. $K_{\mathrm{i}}$ is defined as the concentration of competitor which inhibits $50 \%$ of radioligand binding or degradation. 
at $37^{\circ} \mathrm{C}$ (Fig. $1 \mathrm{~B}$ ) also suggests that the majority of TFPI is not associating with LRP. To examine whether the $39-\mathrm{kD}$ protein was altering the intracellular association of ${ }^{125} \mathrm{I}$-TFPI (and ${ }^{125}$ I-TFPI-160) with LRP, cell monolayers were treated with Pronase after incubation for $4 \mathrm{~h}$ at $37^{\circ} \mathrm{C}$. Pronase treatment digests cell surface radioligand, thereby separating surface (Pronase-sensitive) from internalized radioligand (Pronase-resistant) (24). As seen in Fig. $1 C$, the $39-\mathrm{kD}$ protein has no effect on cell surface-associated ${ }^{125}$ I-TFPI but does inhibit, in a dosedependent manner, ${ }^{125}$ I-TFPI internalization (Fig. $1 D$ ). Fig. 1 $C$ also shows that the $39-\mathrm{kD}$ protein inhibits the cell surface association of ${ }^{125}$ I-TFPI-160 (initial concentration $10 \mathrm{nM}$ ) by $\sim 50 \%(17 \mathrm{fmol} / \mathrm{mg}$ protein in the absence of the $39-\mathrm{kD}$ protein vs $9 \mathrm{fmol} / \mathrm{mg}$ protein in the presence of $1 \mu \mathrm{M} 39-\mathrm{kD}$ protein). Internalization of ${ }^{125} \mathrm{I}$-TFPI-160 (Fig. $1 \mathrm{D}$ ) is also inhibited by the $39-\mathrm{kD}$ protein $(38 \mathrm{fmol} / \mathrm{mg}$ protein in the absence of the $39-\mathrm{kD}$ protein vs $9 \mathrm{fmol} / \mathrm{mg}$ protein in the presence of $1 \mu \mathrm{M}$ $39-\mathrm{kD}$ protein). Fig. $1, B$ and $C$, also demonstrates that in the absence of the $39-\mathrm{kD}$ protein significantly less ${ }^{125} \mathrm{I}$-TFPI-160 is associated with hepatoma cells than full-length ${ }^{125} \mathrm{I}$-TFPI.

Inhibition of ${ }^{125}$ I-TFPI-160 internalization by $39-k D$ protein constructs. To define whether the amino and/or carboxy terminus of the $39-\mathrm{kD}$ protein is responsible for inhibiting ${ }^{125} \mathrm{I}$-TFPI160 internalization, $\mathrm{MH}_{1} \mathrm{C}_{1}$ cells were incubated for $4 \mathrm{~h}$ at $37^{\circ} \mathrm{C}$ with various concentrations of GST fusion proteins encoding residues 1-114 (GST/1-114) and residues 115-319 (GST/ 115-319) of the 39-kD protein. Thereafter, the overlying medium was removed and the cell monolayers were rinsed and treated with Pronase. Fig. 2 demonstrates that GST/115-319 inhibits ${ }^{125}$ I-TFPI-160 internalization (Pronase-resistant) essentially identically to the full-length $39-\mathrm{kD}$ protein with or without GST (GST/1-319 and 1-319, respectively). The $K_{\mathrm{i}}$ values for inhibition of internalization by GST/115-319, GST/1-319, and 1-319 are each $\sim 200 \mathrm{nM}$. Internalization of ${ }^{125} \mathrm{I}$-TFPI160 (initial concentration $10 \mathrm{nM}$ ) is reduced from $\sim 17 \mathrm{fmol} /$ $\mathrm{mg}$ protein in the absence of the $39-\mathrm{kD}$ protein $\mathrm{vs} \sim 4 \mathrm{fmol} /$ $\mathrm{mg}$ protein in the presence of $1 \mu \mathrm{M}$ GST/115-319, GST/1319 , and 1-319. The amino-terminal construct, GST/1-114, inhibits ${ }^{125}$ I-TFPI-160 internalization poorly with a $K_{\mathrm{i}}$ value $\gg 1,000 \mathrm{nM}$. GST alone does not alter ${ }^{125} \mathrm{I}$-TFPI-160 internalization.

Effect of TFPI and TFPI-160 on the binding, cellular association, and cellular degradation of ${ }^{125} I-\alpha_{2} M^{*}$. We reported previously that TFPI inhibits the binding and degradation of ${ }^{125} \mathrm{I}-\alpha_{2} \mathrm{M} *$ by $\mathrm{MH}_{1} \mathrm{C}_{1}$ cells. ${ }^{3}$ Therefore we compared the ability of TFPI with TFPI- 160 to alter ${ }^{125} \mathrm{I}-\alpha_{2} \mathrm{M} *$ binding at $4^{\circ} \mathrm{C}$ and to alter the cellular association/degradation of ${ }^{125} \mathrm{I}-\alpha_{2} \mathrm{M}^{*}$ at $37^{\circ} \mathrm{C}$. Fig. $3 \mathrm{~A}$ demonstrates that TFPI inhibits ${ }^{125} \mathrm{I}-\alpha_{2} \mathrm{M}^{*}$ binding to $\mathrm{MH}_{1} \mathrm{C}_{1}$ cells essentially identically to the $39-\mathrm{kD}$ protein ( $K_{\mathrm{i}}$ values $\sim 20 \mathrm{nM}$ ). $\sim 85 \%$ of specific ${ }^{125} \mathrm{I}-\alpha_{2} \mathrm{M}^{*}$ binding is inhibited by the $39-\mathrm{kD}$ protein $(1 \mu \mathrm{M})$ and TFPI $(1 \mu \mathrm{M})$. In contrast, TFPI-160 only slightly $(\sim 10 \%)$ inhibits ${ }^{125} \mathrm{I}-\alpha_{2} \mathrm{M}^{*}$ binding. TFPI and the $39-\mathrm{kD}$ protein similarly inhibit the cellular association (Fig. $3 B$ ) and cellular degradation of ${ }^{125} \mathrm{I}-\alpha_{2} \mathrm{M}^{*}$ (Fig. $3 \mathrm{C}$ ) at $37^{\circ} \mathrm{C}$, whereas $1 \mu \mathrm{M}$ TFPI-160 inhibits $\sim 10 \%$ of ${ }^{125} \mathrm{I}-\alpha_{2} \mathrm{M} *$ degradation.

Binding of ${ }^{125}$ I-TFPI and ${ }^{125}$ I-TFPI-160 to hepatoma cells. The above findings suggested that only a very small fraction of ${ }^{125}$ I-TFPI-160 associated with the hepatoma cell surface and was

3. Warshawsky, I., J. Herz, G. J. Broze, Jr., and A. L. Schwartz, unpublished observations.

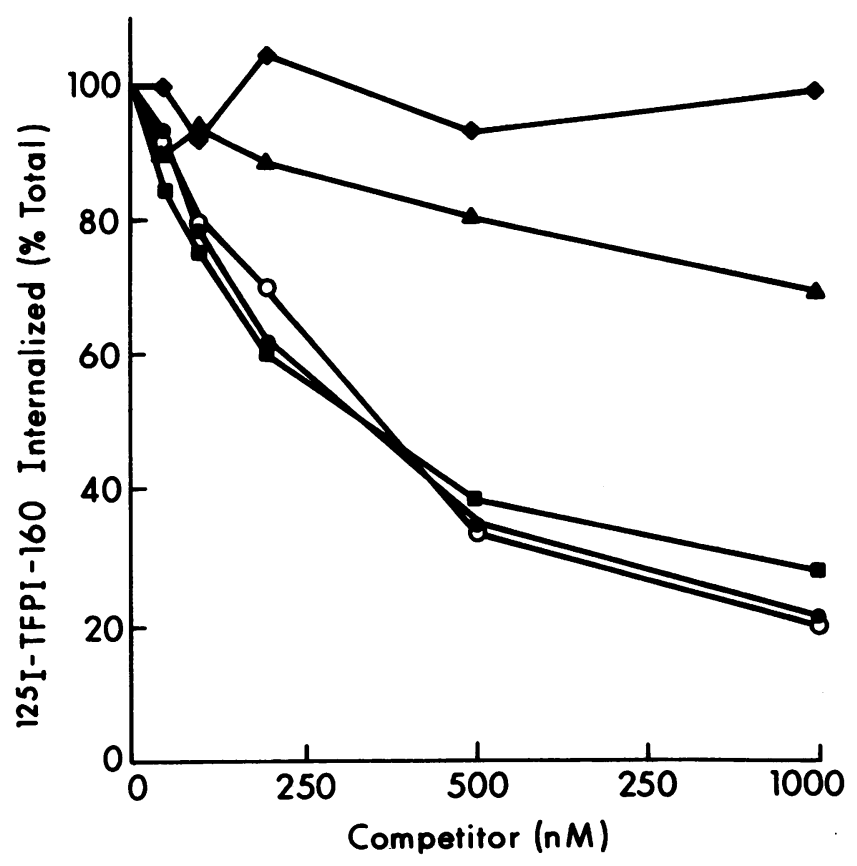

Figure 2. Inhibition of ${ }^{125} \mathrm{I}$-TFPI-160 internalization by $39-\mathrm{kD}$ protein constructs on rat hepatoma $\mathrm{MH}_{1} \mathrm{C}_{1}$ cells. Cells were incubated for $4 \mathrm{~h}$ at $37^{\circ} \mathrm{C}$ with $10 \mathrm{nM}^{125} \mathrm{I}$-TFPI- 160 in the absence or presence of increasing concentrations of various $39-\mathrm{kD}$ protein constructs. Thereafter, the buffers overlying the cell monolayers were removed and the cells were rinsed to remove unbound ligand. The cell monolayers were treated with Pronase, and Pronase-resistant (internalized) ${ }^{125}$ I-TFPI-160 was determined. The constructs used were 1-319 (0), GST/1-319 (•), GST/1-114 (^), GST/115-319 (匹), and as a negative control, GST $(\diamond)$. ${ }^{125} \mathrm{I}$-TFPI-160 internalized in the absence of any $39-\mathrm{kD}$ protein construct was defined as $100 \%$. Each symbol represents the average of duplicate determinations from two separate experiments.

internalized and degraded via LRP. Therefore, we examined whether the third Kunitz-type domain and basic carboxy terminus of TFPI were required for binding to hepatoma cells. The ability of TFPI- 160 to inhibit the binding of full-length ${ }^{125} \mathrm{I}$ TFPI to $\mathrm{MH}_{1} \mathrm{C}_{1}$ cells and the ability of ${ }^{125}$ I-TFPI- 160 to directly bind to $\mathrm{MH}_{1} \mathrm{C}_{1}$ cells were examined. As seen in Fig. 4, unlabeled TFPI inhibits the binding of ${ }^{125}$ I-TFPI $(2.5 \mathrm{nM})$ with a $K_{\mathrm{i}}$ value of $\sim 80 \mathrm{nM}$. Fig. 4 also shows that unlabeled TFPI-160, at concentrations ranging from 20 to $1,000 \mathrm{nM}$, does not effectively inhibit ${ }^{125} \mathrm{I}$-TFPI binding. To examine whether ${ }^{125} \mathrm{I}$-TFPI160 bound specifically to $\mathrm{MH}_{1} \mathrm{C}_{1}$ cells, saturation binding experiments were performed over the concentration range of 5-50 $\mathrm{nM}$. We found that TFPI-160 either did not bind specifically to $\mathrm{MH}_{1} \mathrm{C}_{1}$ cells or that the binding affinity was so low that no discernable $K_{\mathrm{d}}$ value could be obtained from the data (data not shown). Together these results demonstrate that carboxyterminal residues 161-276 are required on TFPI for efficient binding to hepatoma cells.

Effect of heparin and other charged molecules on ${ }^{125}$ I-TFPI binding. Since the basic carboxy terminus of TFPI and a portion of the third Kunitz-type domain have been shown previously to bind heparin $(14,15)$ and since this region is important for TFPI binding to hepatoma cells, the ability of heparin and other charged molecules to alter ${ }^{125} \mathrm{I}$-TFPI binding to $\mathrm{MH}_{1} \mathrm{C}_{1}$ cells was examined. Fig. 5 demonstrates that these molecules inhibit ${ }^{125}$ I-TFPI binding in a dose-dependent manner. The order of potency is: dextran sulfate $\sim$ pentosan polysulfate $>$ heparin 

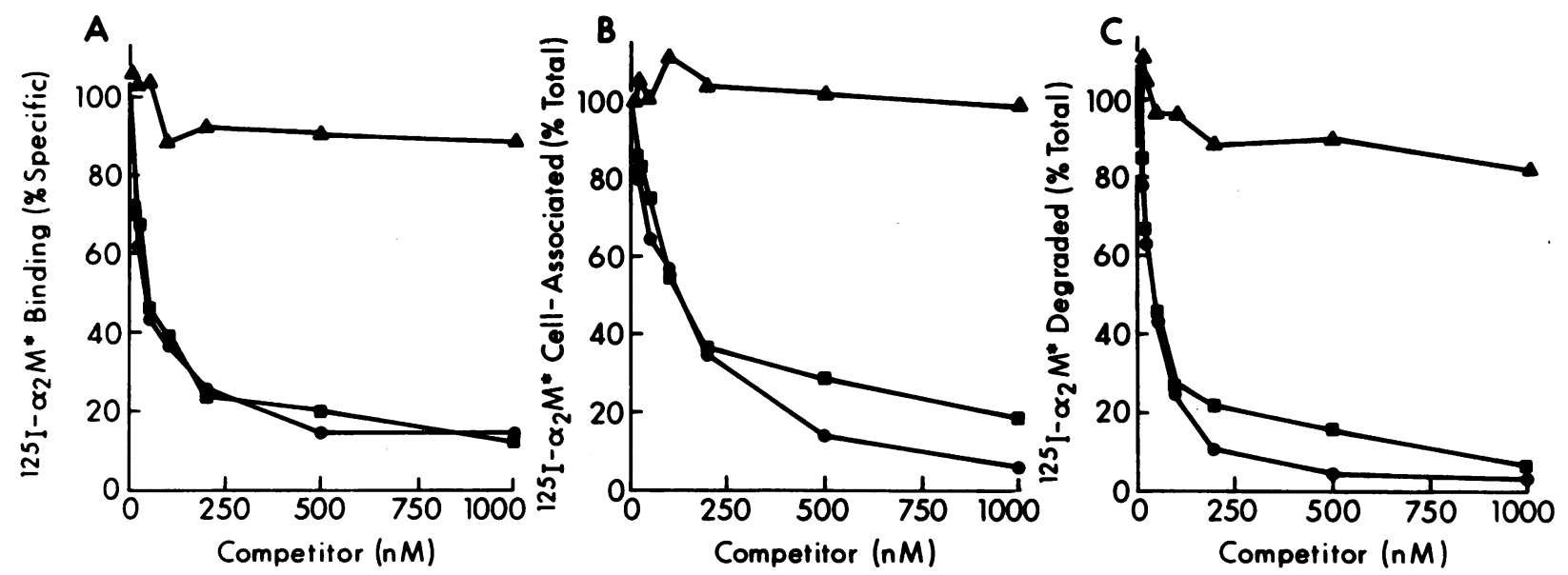

Figure 3. Effect of TFPI, TFPI-160, and the $39-\mathrm{kD}$ protein on the binding, cellular association, and cellular degradation of ${ }^{125} \mathrm{I}-\alpha_{2} \mathrm{M}^{*}$. In $A, \mathrm{MH}_{1} \mathrm{C}_{1}$ cells were incubated for $2 \mathrm{~h}$ at $4^{\circ} \mathrm{C}$ with $50 \mathrm{pM}$ of ${ }^{125} \mathrm{I}-\alpha_{2} \mathrm{M}^{*}$ in the absence or presence of increasing concentrations of unlabeled 39-kD protein $(\bullet)$, TFPI $(\bullet)$, or TFPI-160 ( $\triangle$ ). 100\% binding was determined in the absence of any competitors. Nonspecific binding ( $6 \%$ of total binding) was determined in the presence of $50 \mathrm{nM}$ unlabeled $\alpha_{2} \mathrm{M}^{*}$ and has been subtracted from each point. In $B$ and $C, \mathrm{MH}_{1} \mathrm{C}_{1}$ cells were incubated for $4 \mathrm{~h}$ at $37^{\circ} \mathrm{C}$ with $50 \mathrm{pM}$ of ${ }^{125} \mathrm{I}-\alpha_{2} \mathrm{M}^{*}$ in the absence or presence of increasing concentrations of unlabeled 39-kD protein ( $\bullet$ ), TFPI ( $\bullet$ ), or TFPI-160 $(\Delta)$. Thereafter, the overlying medium was removed and subjected to trichloroacetic acid precipitation. The cell monolayers were washed and cellassociated radioactivity was determined. Cell-associated $(B)$ and degraded (trichloroacetic acid-soluble) $(C){ }^{125} \mathrm{I}-\alpha_{2} \mathrm{M}^{*}$ are indicated. ${ }^{125} \mathrm{I}-\alpha_{2} \mathrm{M}^{*}$ cell-associated or degraded in the absence of any competitor was defined as $100 \%$. Each symbol represents the average of duplicate determinations.

$\sim$ low molecular weight heparin $>$ heparan sulfate $\sim$ poly $L$ lysine $(15-30 \mathrm{kD})>$ chondroitan sulfate $\sim$ poly L-lysine $(1-$ $4 \mathrm{kD})$. Greater than $90 \%$ of ${ }^{125} \mathrm{I}$-TFPI binding could be inhibited at the highest dose of competitor added.

Clearance of ${ }^{125}$ I-TFPI and ${ }^{125}$ I-TFPI-160 in the rat. Since TFPI, but not TFPI-160, was capable of effectively binding to

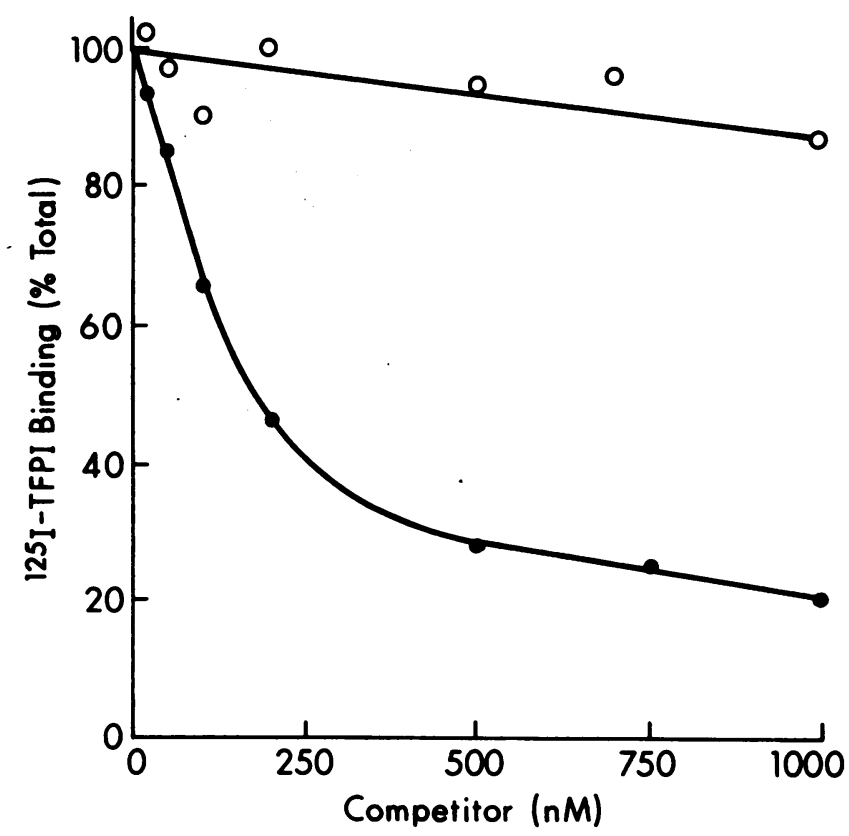

Figure 4. Binding of ${ }^{125}$ I-TFPI to rat hepatoma $\mathrm{MH}_{1} \mathrm{C}_{1}$ cells in the absence or presence of unlabeled TFPI or TFPI-160. Cells were incubated for $2 \mathrm{~h}$ at $4^{\circ} \mathrm{C}$ with $2.5 \mathrm{nM}{ }^{125} \mathrm{I}$-TFPI in the absence or presence of increasing concentrations of unlabeled TFPI $(\bullet)$ or unlabeled TFPI$160(0) .{ }^{125}$ I-TFPI bound in the absence of any competitor was defined as $100 \%$. Each symbol represents the average of duplicate determinations from two separate experiments. hepatoma cells in vitro, the fates of TFPI and TFPI-160 were examined in vivo. Approximately $6-8 \times 10^{6} \mathrm{cpm}$ of ${ }^{125} \mathrm{I}$-TFPI and ${ }^{125}$ I-TFPI-160 was intravenously injected into the tail veins of rats. The disappearance of ${ }^{125}$ I-radioactivity (trichloroacetic acid-precipitable) from rat plasma was followed over time. Fig. $6 \mathrm{~A}$ demonstrates that ${ }^{125} \mathrm{I}$-TFPI disappears rapidly from the plasma with an initial half-life of $\sim 30 \mathrm{~s}$. Approximately $20 \%$ of the administered dose of ${ }^{125}$ I-TFPI remained in the circulation between 1 and $10 \mathrm{~min}$. At $10 \mathrm{~min}$ after intravenous

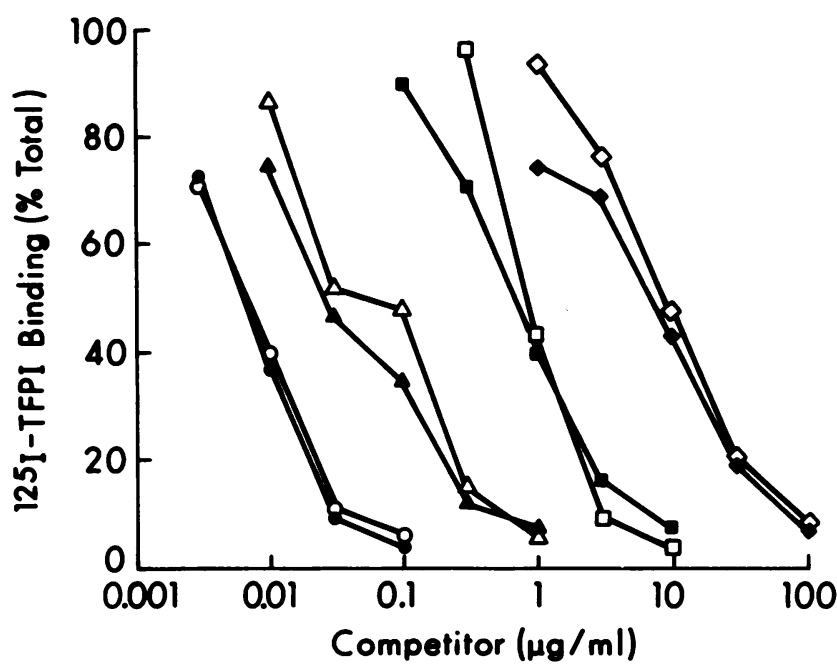

Figure 5. Effect of heparin and other charged molecules on ${ }^{125}$ I-TFPI binding. $\mathrm{MH}_{1} \mathrm{C}_{1}$ cells were incubated for $2 \mathrm{~h}$ at $4^{\circ} \mathrm{C}$ with $2.5 \mathrm{nM}{ }^{125} \mathrm{I}$ TFPI in the absence or presence of increasing concentrations of dextran sulfate $(\bullet)$, pentosan polysulfate $(0)$, heparin $(\bullet)$, low molecular weight heparin $(\Delta)$, heparan sulfate $(\square)$, poly L-lysine $(15-30 \mathrm{kD})$ $(\square)$, chondroitan sulfate $(\bullet)$, and poly L-lysine (1-4 kD) ( $\diamond) .100 \%$ binding was determined in the absence of any competitors. Each symbol represents the average of duplicate determinations from one to three separate experiments. 

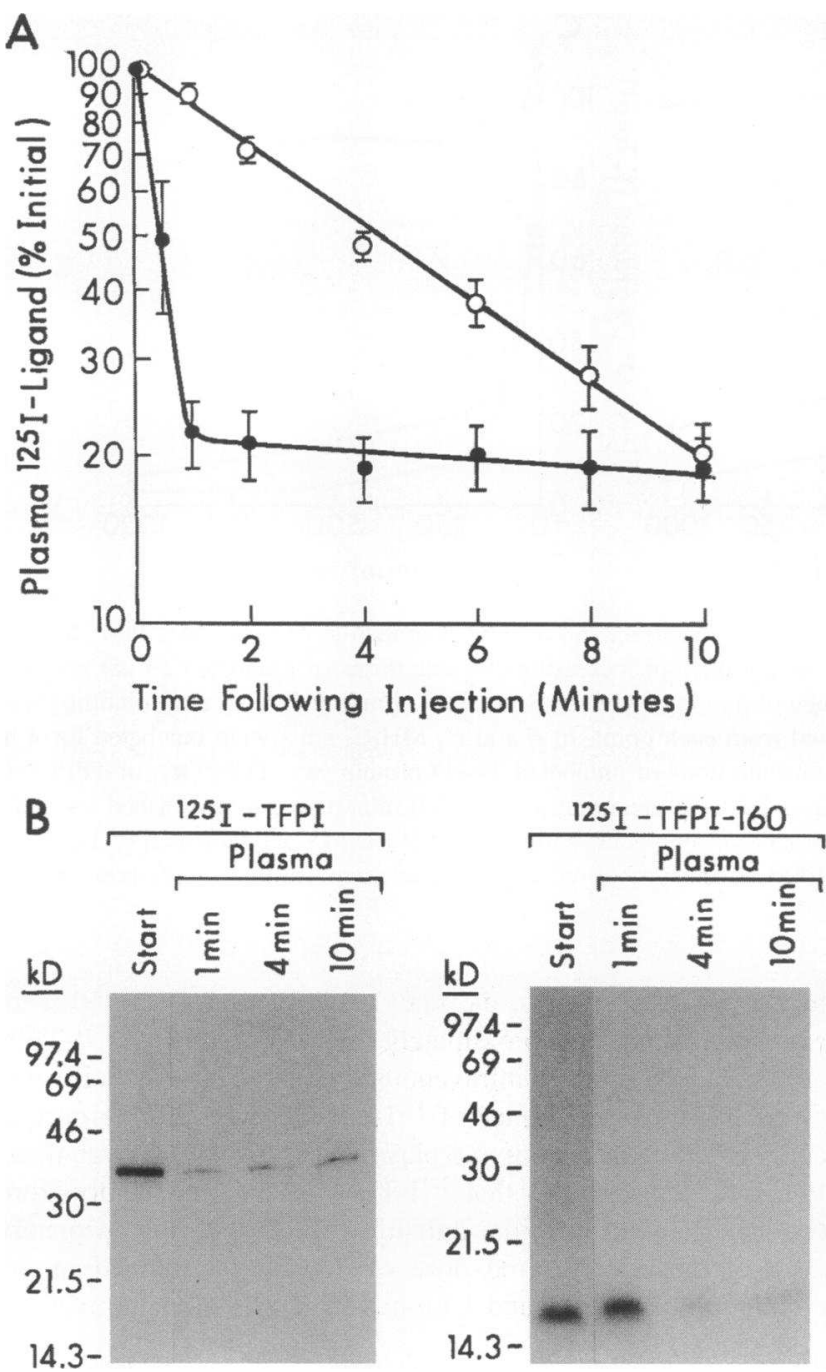

Figure 6. (A) Clearance of ${ }^{125} \mathrm{I}$-TFPI and ${ }^{125} \mathrm{I}$-TFPI-160 in the rat. Rats were injected with $6-8 \times 10^{6} \mathrm{cpm}$ of ${ }^{125}$ I-TFPI $(\bullet)(n=7$ rats $)$ or ${ }^{125}$ I-TFPI-160 (O) $(n=4$ rats $)$. Blood samples were collected at the indicated times and trichloroacetic acid-insoluble radioactivity was determined. Each symbol represents the mean \pm SEM. $(B)$ SDS-PAGE of plasma samples. Plasma samples collected 1,4 , and 10 min after intravenous administration of ${ }^{125}$ I-TFPI (left) or ${ }^{125}$ I-TFPI-160 (right) were immunoprecipitated with anti-TFPI IgG. Immunoprecipitates of the plasma samples, as well as immunoprecipitates of the starting ${ }^{125}$ I-TFPI or ${ }^{125} \mathrm{I}$-TFPI-160, were analyzed by $12.5 \%$ SDS-PAGE. Gels were exposed to film $3 \mathrm{~d}$ (TFPI samples), $20 \mathrm{~h}$ (start TFPI-160), or $4 \mathrm{~d}$ (TFPI160 plasma samples) before developing. Molecular mass markers in kilodaltons are indicated.

injection, the percentages of ${ }^{125}$ I-TFPI associating with the liver, kidneys, and spleen were $25, \sim 2$, and $<1 \%$ of the injected dose, respectively (Table I). Fig. $6 \mathrm{~A}$ also shows that ${ }^{125}$ I-TFPI160 disappears rapidly from the circulation after intravenous administration. ${ }^{125}$ I-TFPI-160 clearance was linear over $10 \mathrm{~min}$ and the plasma half-life was $\sim 4 \mathrm{~min}$. At $10 \mathrm{~min}, \sim 20 \%$ of the injected dose remained in the circulation. The amount of ${ }^{125}$ I-TFPI-160 associating with the liver, kidneys, and spleen was determined $10 \min (n=2$ rats $), 15 \min (n=1$ rat $)$, and $35 \min (n=1$ rat $)$ after intravenous administration of ${ }^{125} \mathrm{I}$ TFPI-160. The organ distributions were similar at the three time points and were therefore averaged. As seen in Table $I$, and in
Table I. Tissue Distribution of ${ }^{125}$ I-Radioactivity after Intravenous Injections of ${ }^{125}$ I-TFPI or ${ }^{125}$ I-TFPI-160

\begin{tabular}{lcccr}
\hline & \multicolumn{3}{c}{ Percent ${ }^{125}$ I-radioactivity/organ } \\
\cline { 2 - 4 }${ }^{125}$ I-Ligand & Liver & Kidney & Spleen & $n$ \\
\hline TFPI & $25 \pm 3.2$ & $2.4 \pm 0.72$ & $0.71 \pm 0.12$ & 7 \\
TFPI-160 & $9.0 \pm 0.87$ & $77 \pm 10.9$ & $1.0 \pm 0.07$ & 4 \\
\hline
\end{tabular}

Seven rats were injected with $6-8 \times 10^{6} \mathrm{cpm}$ of ${ }^{125}$ I-TFPI. After 10 min, the animals were killed, organs were obtained, and their content of ${ }^{125}$ I-radioactivity was determined. Four rats were injected with 6-8 $\times 10^{6} \mathrm{cpm}$ of ${ }^{125}$ I-TFPI-160. After $10 \mathrm{~min}(n=2 \mathrm{rats}), 15 \mathrm{~min}(n=1$ rat), or $35 \min \left(n=1\right.$ rat), the animals were killed and ${ }^{125}$ I-radioactivity associating with the liver, kidneys, and spleen was determined. $n$, number of animals in each group. Data are expressed as mean \pm SEM.

marked contrast to the results with ${ }^{125}$ I-TFPI, 9,77 , and $1 \%$ of the injected ${ }^{125}$ I-TFPI-160 accumulated in the liver, kidneys, and spleen, respectively.

Plasma samples obtained 1, 4, and $10 \mathrm{~min}$ after the intravenous administration of ${ }^{125} \mathrm{I}$-TFPI and ${ }^{125} \mathrm{I}$-TFPI- 160 into rats were subjected to immunoprecipitation with anti-TFPI antibodies. After SDS-PAGE and autoradiography, both ${ }^{125}$ I-TFPI and ${ }^{125}$ I-TFPI-160 were found to migrate identically to the starting ${ }^{125}$ I-labeled proteins (Fig. $6 \mathrm{~B}$ ). Fig. $6 \mathrm{~B}$ also shows that the disappearance of ${ }^{125}$ I-TFPI and ${ }^{125}$ I-TFPI- 160 over time on SDSPAGE parallels the disappearance seen in Fig. 6 A. Furthermore, ${ }^{125}$ I-TFPI could be immunoprecipitated from plasma samples obtained 1, 4, and $10 \mathrm{~min}$ after intravenous administration using a carboxy-terminal antipeptide rabbit antibody generated against amino acids 265-276 of TFPI (14) (data not shown). These results demonstrate that full-length TFPI is not being proteolyzed at the carboxy terminus for at least $10 \mathrm{~min}$ after its intravenous administration.

Sites of ${ }^{125}$ I-TFPI and ${ }^{125}$ I-TFPI-160 clearance. Tissue sections of kidney and liver were prepared after the in vivo administration of $6-8 \times 10^{6} \mathrm{cpm}$ of ${ }^{125} \mathrm{I}$-TFPI and ${ }^{125} \mathrm{I}$-TFPI-160. ${ }^{125} \mathrm{I}$ Radioactivity localizes to the outer cortex of the kidney in rats injected with ${ }^{125}$ I-TFPI (Fig. $7 \mathrm{~A}$ ) and ${ }^{125} \mathrm{I}$-TFPI-160 (Fig. 7 $B)$. The intensity of radioactivity is substantially greater in the kidneys of rats injected with ${ }^{125}$ I-TFPI- 160 than in rats injected with ${ }^{125}$ I-TFPI. The patterns of radioactivity in the livers from rats injected with ${ }^{125} \mathrm{I}$-TFPI and ${ }^{125} \mathrm{I}$-TFPI-160 were homogenous. The intensity of radioactivity was substantially greater in the livers of rats injected with ${ }^{125}$ I-TFPI than in rats injected with ${ }^{125}$ I-TFPI-160. To examine which cell type (s) in the kidney and liver accumulated ${ }^{125}$ I-TFPI and ${ }^{125}$ I-TFPI-160, kidney and liver sections were prepared $10 \mathrm{~min}$ after their intravenous injections and examined by microscopic autoradiography. Fig. $8 \mathrm{~A}$ ( $\times 300,3-w k$ exposure) is a hematoxylin and eosin-stained autoradiogram of a kidney section from a rat injected with ${ }^{125} \mathrm{I}$ TFPI. The grains localize both to the glomeruli and to the cells of the proximal tubules (predominantly on the apical surface). Autoradiograms of kidney sections from a rat administered ${ }^{125} \mathrm{I}$ TFPI-160 are seen in Fig. $8 B(\times 300,2-d$ exposure $), 8 C(\times 200$, 3-wk exposure), and $8 D$ ( $\times 100,3$-wk exposure). As seen, the vast majority of the grains are located in cells of the proximal tubules and are largely on the apical surface. Only a very minor fraction of the grains is glomerular. Fig. 8, $E$ and $F(\times 200,3-$ wk exposures), are autoradiograms of liver sections from rats injected with ${ }^{125}$ I-TFPI and ${ }^{125}$ I-TFPI-160, respectively. The ma- 

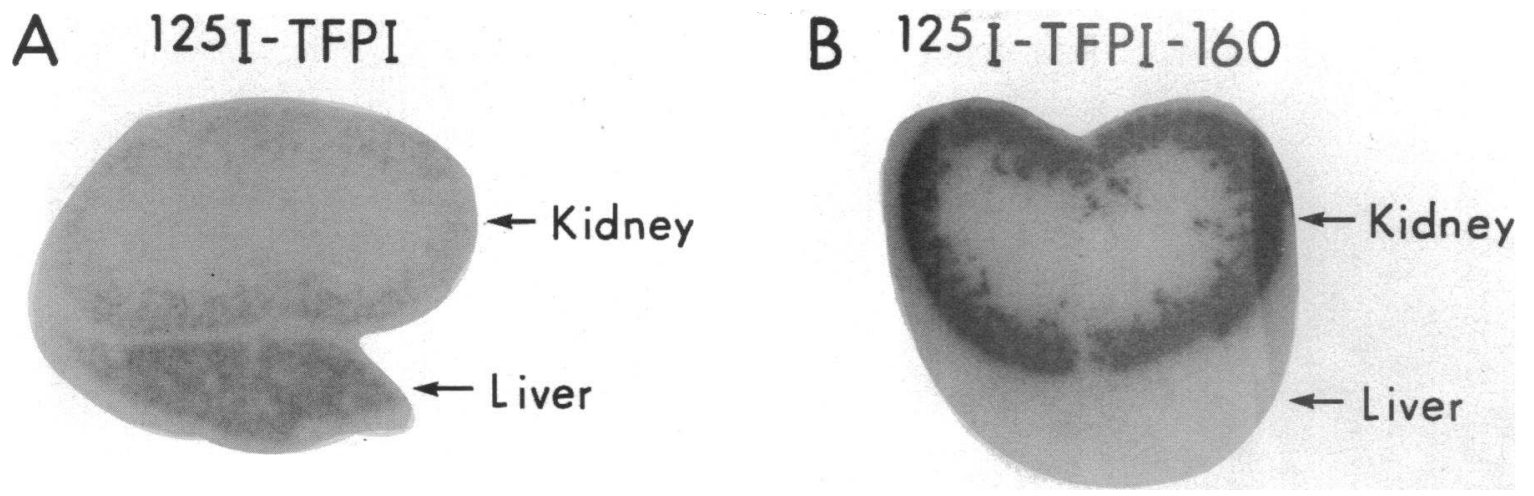

Figure 7. Autoradiograms of kidney and liver sections from rats injected with ${ }^{125}$ I-TFPI or ${ }^{125}$ I-TFPI-160. Rats were killed 10 min after intravenous administration of 6-8 $\times 10^{6} \mathrm{cpm}$ of ${ }^{125} \mathrm{I}$-TFPI $(A)$ or ${ }^{125} \mathrm{I}$-TFPI-160 $(B)$. The kidneys and liver were dissected out and fixed with formalin. Paraffinembedded sections were prepared and exposed to film $40 \mathrm{~d}$ before developing.

jority of the grains is hepatocellular and neither ${ }^{125} \mathrm{I}$-TFPI nor ${ }^{125} \mathrm{I}-$ TFPI-160 appears to significantly localize to the hepatic vascular endothelium. Significantly more grains are seen in the livers of rats injected with ${ }^{125} \mathrm{I}$-TFPI than ${ }^{125} \mathrm{I}$-TFPI- 160 .

\section{Discussion}

In this study, we have demonstrated that carboxy-terminal residues 161-276 of TFPI are required for its specific binding to hepatoma cells in vitro and in vivo. TFPI-160, which contains the first two Kunitz-type domains and lacks the third Kunitztype domain and basic carboxy terminus, neither binds specifically to cultured hepatoma cells nor inhibits the binding of fulllength ${ }^{125} \mathrm{I}$-TFPI to hepatoma cells at concentrations ranging from 20 to $1,000 \mathrm{nM}$. In addition, TFPI-160 only has a slight effect on the binding and cellular degradation of ${ }^{125} \mathrm{I}-\alpha_{2} \mathrm{M}^{*}$ whereas TFPI completely inhibits each of these processes. Moreover, after intravenous administration of ${ }^{125} \mathrm{I}$-TFPI and ${ }^{125} \mathrm{I}$ TFPI-160 into rats, ${ }^{125} \mathrm{I}$-TFPI accumulates predominantly in the liver, whereas ${ }^{125}$ I-TFPI-160 accumulates in the outer cortex of the kidneys. The clearance curve we obtained after injection of tracer doses of full-length ${ }^{125}$ I-TFPI into rats is similar to those described previously after bolus or tracer dose administration of TFPI into rabbits $(17,18,25)$, baboons $(26)$, and rats (27) in that the alpha phase of clearance is extremely rapid. The reported beta phase half-lives vary from $17 \mathrm{~min}$ to $2 \mathrm{~h}(17,18$, 26). The recoveries of TFPI in plasma between $10 \mathrm{~min}$ and 4 $\mathrm{h}$ after intravenous administration also vary (from $\sim 3$ to $\sim 40 \%$ ) and may reflect differences in the TFPI preparations administered $(17,18,25-27)$. We found that between 1 and 10 min, $\sim 20 \%$ of the injected ${ }^{125}$ I-TFPI was still remaining in the circulation (Fig. $6 \mathrm{~A}$ ), and at $10 \mathrm{~min}, 25 \%$ was associated with the liver. It is not clear where the remaining $55 \%$ of injected ${ }^{125}$ I-TFPI accumulates. Circumstantial evidence suggests that TFPI may be bound to heparan sulfate proteolglycans or glycosaminoglycans on the endothelial cell surface. This hypothesis is based on the observations that: (a) TFPI binds to heparin agarose $(14) ;(b)$ heparin and sulfated polysaccharides enhance the anticoagulant activity of TFPI (28); and (c) after intravenous administration of heparin, plasma levels of TFPI increase severalfold $(8,29)$. Thus it is possible that the $55 \%$ of ${ }^{125} \mathrm{I}$-TFPI is bound to the vascular endothelium in various tissues. The observation that the vast majority of ${ }^{125}$ I-TFPI clearance was hepatocellular and not associated with the hepatic vascular endothelium (Fig. $8 E$ ), however, argues against ${ }^{125} \mathrm{I}$ TFPI being bound to the vascular endothelium.

In sharp contrast to the hepatocellular accumulation of ${ }^{125} \mathrm{I}$ TFPI, ${ }^{125}$ I-TFPI-160 accumulated mainly in the cells of renal proximal tubules (Fig. 8, $B-D$ ). The small fraction of ${ }^{125} \mathrm{I}$-TFPI that associated with the kidneys also localized to the proximal tubules as well as to the glomeruli (Fig. $8 \mathrm{~A}$ ). The vastly different tissue distribution observed with TFPI and TFPI-160 suggests that the third Kunitz-type domain and/or carboxy terminus confers liver specificity. It is also possible that the acidic amino terminus and/or first two Kunitz-type domains confers kidney specificity. It is not clear whether TFPI and TFPI-160 are being filtered/reabsorbed. It is also not clear whether TFPI and TFPI160 are binding specifically to a renal protein although a likely candidate would be glycoprotein 330 (gp330), a member of the LDL-receptor family that localizes to clathrin-coated pits of kidney proximal tubules and glomerular epithelium (3032). It is interesting to note that $\alpha_{2} \mathbf{M}^{*}$ does not bind to gp330 $(33,34)$, and that TFPI-160, which associates with the kidney after intravenous administration, only slightly alters the binding and cellular degradation of ${ }^{125} \mathrm{I}-\alpha_{2} \mathrm{M}^{*}$. The potential involvement of gp330 in the endocytic internalization of TFPI and TFPI-160 will be the subject of future studies.

We reported previously that, after TFPI binding to the hepatoma cell surface, LRP mediates the cellular degradation of TFPI since both antibodies directed against LRP as well as the full-length $39-\mathrm{kD}$ protein or residues $115-319$ of the $39-\mathrm{kD}$ protein each inhibit $>80 \%$ of ${ }^{125}$ I-TFPI degradation (19). ${ }^{3}$ In addition, we reported that LRP was not the major hepatic cell surface receptor for TFPI since ${ }^{125} \mathrm{I}$-TFPI binding at $4^{\circ} \mathrm{C}$ was not inhibited by the $39-\mathrm{kD}$ protein (19). In the current study, we found ${ }^{125}$ I-TFPI internalization (Pronase-resistant) but not the total cellular association (i.e., cell surface plus internalized) or cell surface association (Pronase-sensitive) of ${ }^{125}$ I-TFPI could be inhibited by the $39-\mathrm{kD}$ protein. This is consistent with the notion that the majority of ${ }^{125} \mathrm{I}$-TFPI is not binding to LRP but that TFPI uptake and degradation occurs via LRP.

Since TFPI-160, which lacks the basic heparin-binding carboxy terminus of TFPI, did not bind to hepatoma cells, we examined whether heparin and related negatively charged molecules altered ${ }^{125}$ I-TFPI binding. We found that heparin, as well as other sulfated polysaccharides, inhibited ${ }^{125}$ I-TFPI binding. However, it is not clear at present whether inhibition resulted from direct competition for the cell surface TFPI-binding pro- 

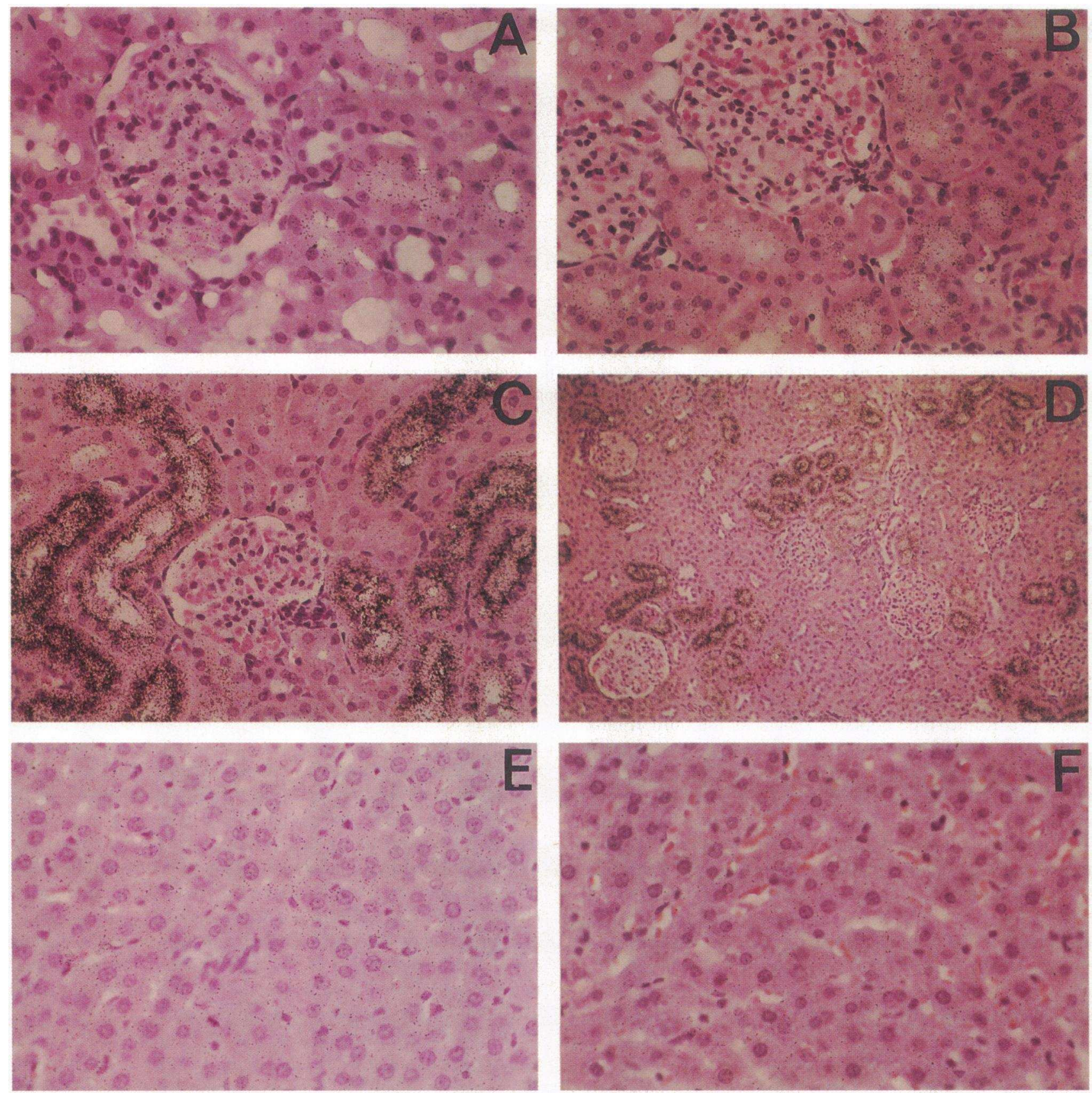

Figure 8. Microscopic autoradiograms of kidney and liver sections from rats injected with ${ }^{125}$ I-TFPI or ${ }^{125}$ I-TFPI-160. Rats were intravenously injected with $6-8 \times 10^{6} \mathrm{cpm}$ of ${ }^{125}$ I-TFPI or ${ }^{125}$ I-TFPI-160. After $10 \mathrm{~min}$, the kidneys and livers were removed and paraffin-embedded sections were processed for autoradiography and stained with hematoxylin and eosin. $(A){ }^{125}$ I-TFPI, kidney, 3-wk exposure, $\times 300$. $(B){ }^{125}$ I-TFPI-160, kidney, 2-d exposure, $\times 300$. (C) ${ }^{125}$ I-TFPI-160, kidney, 3-wk exposure, $\times 200$. (D) ${ }^{125}$ I-TFPI-160, kidney, 3-wk exposure, $\times 100$. $(E){ }^{125}$ I-TFPI, liver, 3-wk exposure, $\times 200$. $(F)^{125}$ I-TFPI-160, liver, 3-wk exposure, $\times 200$.

tein or whether these molecules bound directly to TFPI (i.e., to the basic carboxy terminus), thereby preventing ${ }^{125}$ I-TFPI from binding to the cell surface and yielding apparent inhibition of binding. These results may suggest that the primary TFPI-binding species on hepatoma cells is acidic. Inhibition of ${ }^{125}$ I-TFPI binding by poly L-lysine may have resulted from poly L-lysine binding to the acidic TFPI-binding species on the hepatoma cell surface and thus preventing ${ }^{125}$ I-TFPI from binding.

We reported previously that carboxy-terminal residues $115-$ 319 of the $39-\mathrm{kD}$ protein, generated as a fusion protein with GST, inhibit the cellular degradation of ${ }^{125}$ I-TFPI essentially identically to the full-length $39-\mathrm{kD}$ protein, GST/1-319. $\mathrm{Al}$ though the $4^{\circ} \mathrm{C}$ binding assays demonstrated that TFPI- $160 \mathrm{did}$ not interact with hepatoma cells to a substantial degree (Fig. 4 ), we examined whether TFPI-160 was capable of interacting with LRP by testing whether the $39-\mathrm{kD}$ protein altered TFPI160 degradation by cultured hepatoma cells. After incubation at $37^{\circ} \mathrm{C}$, we found that the $39-\mathrm{kD}$ protein inhibited the cellular association, internalization, and degradation of ${ }^{125}$ I-TFPI- 160 (Fig. 1, $B-D$ ). Similar to the results obtained with full-length TFPI, residues $115-319$ of the $39-\mathrm{kD}$ protein inhibited TFPI160 internalization essentially identically to the full-length 39 - 
$\mathrm{kD}$ protein (Fig. 2). The relative amount of TFPI-160 internalized and degraded, however, was markedly less than that seen with full-length TFPI. This suggests that the third Kunitz-type domain and/or the basic carboxy terminus contains residues important for interaction with LRP. Alternatively, it is possible that TFPI may be optimally recognized by LRP only while bound to the primary TFPI-binding species.

\section{Acknowledgments}

We thank the Monsanto Company for generously providing the purified TFPI.

This work was supported in part by grants HL-52040, HL-53280, and HL-34462 from the National Institutes of Health. I. Warshawsky is supported in part by the Cardiovascular Training Grant in Molecular Biology and Pharmacology (T32HL07275).

\section{References}

1. Rapaport, S. I. 1989. Inhibition of Factor VIIa/tissue factor-induced blood coagulation: with particular emphasis upon a Factor Xa-dependent inhibitory mechanism. Blood. 73:359-365.

2. Broze, G. J., Jr. 1992. The role of tissue factor pathway inhibitor in a revised coagulation cascade. Semin. Hematol. 29:159-169.

3. Schneider, C. L. 1947. The active principle of placental toxin: thromboplastin; its inactivator in blood: antithromboplastin. Am. J. Physiol. 149:123-129.

4. Thomas, L. 1947. Studies on the intravascular thromboplastin effect of tissue suspensions in mice. II. A factor in normal rabbit serum which inhibits the thromboplastin effect of the sedimentable tissue component. Bull. Johns Hopkins Hosp. 81:26-42.

5. Broze, G. J., Jr., L. A. Warren, T. J. Girard, and J. P. Miletich. 1987. Isolation of the lipoprotein associated coagulation inhibitor produced by HepG2 (human hepatoma) cells using bovine Factor $\mathrm{Xa}$ affinity chromatography. Thromb. Res. 48:253-259.

6. Broze, G. J., Jr., and J. P. Miletich. 1987. Isolation of the tissue factor inhibitor produced by HepG2 hepatoma cells. Proc. Natl. Acad. Sci. USA 84:1886-1890.

7. Novotny, W. F., T. J. Girard, J. P. Miletich, and G. J. Broze, Jr. 1989. Purification and characterization of the lipoprotein-associated coagulation inhibitor from human plasma. J. Biol. Chem. 264:18832-18837.

8. Novotny, W. F., M. Palmier, T.-C. Wun, G. J. Broze, Jr., and J. P. Miletich. 1991. Purification and properties of heparin-releasable lipoprotein-associated coagulation inhibitor. Blood. 78:394-400.

9. Wun, T.-C., K. K. Kretzmer, T. J. Girard, J. P. Miletich, and G. J. Broze, Jr. 1988. Cloning and characterization of a cDNA coding for the lipoproteinassociated coagulation inhibitor shows that it consists of three tandem Kunitztype inhibitory domains. J. Biol. Chem. 263:6001-6004.

10. Broze, G. J., Jr., L. A. Warren, W. F. Novotny, D. A. Higuchi, T. J. Girard, and J. P. Miletich. 1988. The lipoprotein-associated coagulation inhibitor which inhibits the Factor VII-tissue factor complex, also inhibits Factor Xa: insight into its possible mechanism of action. Blood. 71:335-343.

11. Girard, T. J., L. A. Warren, W. F. Novotny, K. M. Likert, S. G. Brown, J. P. Miletich, and G. J. Broze, Jr. 1989. Functional significance of the Kunitztype inhibitory domains of lipoprotein-associated coagulation inhibitor. Nature (Lond.). 338:518-520.

12. Broze, G. J., Jr., G. W. Lange, K. L. Duffin, and L. MacPhail. 1994 Heterogeneity of plasma tissue factor pathway inhibitor (TFPI). Blood Coagul. \& Fibrinolysis. 5:551-559.

13. Hamamoto, T., M. Yamamoto, O. Nordfang, J. G. L. Petersen, D. C. Foster, and W. Kisiel. 1993. Inhibitory properties of full-length and truncated recombinant tissue factor pathway inhibitor (TFPI). J. Biol. Chem. 268:87048710.

14. Wesselschmidt, R., K. Likert, T. Girard, T.-C. Wun, and G. J. Broze, Jr. 1992. Tissue factor pathway inhibitor: the carboxy-terminus is required for optimal inhibition of Factor Xa. Blood. 79:2004-2010.

15. Wesselschmidt, R., K. Likert, Z.-F. Huang, L. MacPhail, and G. J. Broze, Jr. 1993. Structural requirements for tissue factor pathway inhibitor interactions with Factor Xa and heparin. Blood Coagul. \& Fibrinolysis. 4:661-669.

16. Nordfang, O., S. E. Bjorn, S. Valentin, L. S. Nielsen, P. Wildgoose, T. C. Beck, and U. Hedner. 1991. The C-terminus of tissue factor pathway inhibitor is essential to its anticoagulant activity. Biochemistry. 30:10371-10376.

17. Palmier, M. O., L. J. Hall, C. M. Reisch, M. K. Baldwin, A. G. E. Wilson, and T.-C. Wun. 1992. Clearance of recombinant tissue factor pathway inhibitor (TFPI) in rabbits. Thromb. Haemostasis. 68:33-36.

18. Bregengaard, C., O. Nordfang, P. Ostergaard, J. G. L. Petersen, G. Meyn, V. Diness, O. Svendsen, and U. Hedner. 1993. Pharmacokinetics of full-length and two-domain tissue factor pathway inhibitor in combination with heparin in rabbits. Thromb. Haemostasis. 70:454-457.

19. Warshawsky, I., G. J. Broze, Jr., and A. L. Schwartz. 1994. The low density lipoprotein receptor-related protein mediates the cellular degradation of tissue factor pathway inhibitor. Proc. Natl. Acad. Sci. USA. 91:6664-6668.

20. Diaz-Collier, J. A., M. O. Palmier, K. K. Kretzmer, B. F. Bishop, R. G. Combs, M. G. Obukowicz, R. B. Frazier, G. S. Bild, W. D. Joy, S. R. Hill, et al. 1994. Refold and characterization of recombinant tissue factor pathway inhibitor expressed in Escherichia coli. Thromb. Haemostasis. 71:339-346.

21. Warshawsky, I., G. Bu, and A. L. Schwartz. 1993. Identification of domains on the 39-kDa protein that inhibit the binding of ligands to the low density lipoprotein receptor-related protein. J. Biol. Chem. 268:22046-22054.

22. Bu, G., P. A. Morton, and A. L. Schwartz. 1992. Identification and partial characterization by chemical cross-linking of a binding protein for tissue-type plasminogen activator (t-PA) on rat hepatoma cells. J. Biol. Chem. 267:1559515602.

23. Laemmli, U. K. 1970. Cleavage of structural proteins during the assembly of the head of bacteriophage $\mathrm{T}_{4}$. Nature (Lond.). 227:680-685.

24. Owensby, D. A., P. A. Morton, and A. L. Schwartz. 1989. Quantitative evaluation of receptor-mediated endocytosis. Methods Cell Biol. 32:305-328.

25. Novotny, W. F., M. Palmier, T.-C. Wun, G. J. Broze, Jr., and J. P. Miletich. 1991. Purification and properties of heparin-releasable lipoprotein-associated coagulation inhibitor. Blood. 78:394-400.

26. Creasey, A. A., A. C. K. Chang, L. Feigen, T.-C. Wun, F. B. Taylor, Jr., and L. B. Hinshaw. 1993. Tissue factor pathway inhibitor reduces mortality from Escherichia coli septic shock. J. Clin. Invest. 91:2850-2860.

27. Smith, P. L., T. P. Skelton, D. Fiete, S. M. Dharmesh, M. C. Beranek, L. MacPhail, G. J. Broze, Jr., and J. U. Baenziger. 1992. The asparagine-linked oligosaccharides on tissue factor pathway inhibitor terminate with $\mathrm{SO}_{4}-4 \mathrm{Gal}$ NAc $\beta 1$, 4GlcNAc $\beta 1$,2Man $\alpha$. J. Biol. Chem. 267:19140-19146.

28. Wun, T.-C. 1992. Lipoprotein-associated coagulation inhibitor (LACI) is a cofactor for heparin: synergistic anticoagulant action between LACI and sulfated polysaccharides. Blood. 79:430-438.

29. Sandset, P. M., U. Abildgaard, and M. L. Larsen. 1988. Heparin induces release of extrinsic coagulation pathway inhibitor (EPI). Thromb. Res. 50:803813.

30. Raychowdhury, R., J. L. Niles, R. T. McCluskey, and J. A. Smith. 1989. Autoimmune target in Heymann nephritis is a glycoprotein with homology to the LDL receptor. Science (Wash. DC). 244:1163-1165.

31. Kerjaschki, D., and M. G. Farquhar. 1983. Immunocytochemical localization of the Heymann nephritis antigen (gp330) in glomerular epithelial cells of normal Lewis rats. J. Exp. Med. 157:667-686.

32. Kerjaschki, D., A. Miettinen, and M. G. Farquhar. 1987. Initial events in the formation of immune deposits in passive Heymann nephritis. J. Exp. Med. $166: 109-128$

33. Kounnas, M. Z., D. A. Chappell, D. K. Strickland, and W. S. Argraves. 1993. Glycoprotein 330 , a member of the low density lipoprotein family, binds lipoprotein lipase in vitro. J. Biol. Chem. 268:14176-14181.

34. Moestrup, S. K., S. Nielsen, P. A. Andreasen, K. E. Jorgensen, A. Nykjaer, H. Roigaard, J. Gliemann, and E. I. Christensen. 1993. Epithelial glycoprotein330 mediates endocytosis of plasminogen activator-plasminogen activator inhibitor type-1 complexes. J. Biol. Chem. 268:16564-16570. 